\title{
Role of the Pruritic Cytokine IL-31 in Autoimmune Skin Diseases
}

\author{
Bernhard F. Gibbs, Nikolaos Patsinakidis and Ulrike Raap* \\ Division of Experimental Allergy and Immunodermatology, University of Oldenburg, Oldenburg, Germany
}

OPEN ACCESS

Edited by:

Ralf J. Ludwig,

Universität zu Lübeck, Germany

Reviewed by:

Zhi Liu,

University of North Carolina at Chape Hill, United States Victoria Patricia Werth, University of Pennsylvania, United States

*Correspondence: Ulrike Raap raap.ulrike@klinikum-oldenburg.de

Specialty section:

This article was submitted to Autoimmune and Autoinflammatory

Disorders,

a section of the journal

Frontiers in Immunology

Received: 25 March 2019 Accepted: 31 May 2019

Published: 21 June 2019

Citation:

Gibbs BF, Patsinakidis N and Raap U (2019) Role of the Pruritic Cytokine

IL-31 in Autoimmune Skin Diseases.

Front. Immunol. 10:1383.

doi: 10.3389/fimmu.2019.01383
Many autoimmune skin diseases, such as bullous pemphigoid (BP), psoriasis and certain types of chronic urticaria, are associated with intensive pruritus. While histamine and neuropeptides have previously been ascribed to play a role in itch that accompanies these diseases, recent evidence suggests that the pruritogenic cytokine interleukin (IL)-31 is a major driver of pruritic responses. IL-31 was originally shown to be produced by activated helper T cells, particularly Th2 cells, mast cells, macrophages and dendritic cells. However, more recent evidence demonstrated that eosinophils are a major source of this cytokine too, particularly in bullous pemphigoid. Basophils have also been shown to express the cytokine which, through autocrine action, strongly supports the production of other Th2-type cytokines from these cells. These investigations suggest that the dynamic recruitment of eosinophils and basophils in some autoimmune skin diseases could play an important role in the severity of IL-31-mediated itch. Furthermore, these studies suggest that IL-31, in addition to its pruritic actions, also has potential immunomodulatory roles in terms of supporting Th2-type immunity, which often underpins IgE-associated autoimmune diseases (such as bullous pemphigoid and urticaria) as well as allergies. While the role of IL-31 in psoriasis remains to be clarified, current evidence shows that this cytokine plays a major role in $\mathrm{BP}$, chronic spontaneous urticaria and dermatomyositis. This suggests potential use of IL-31 receptor-blocking therapeutic approaches (e.g., Nemolizumab) for the treatment of IL-31-associated disorders.

Keywords: IL-31, itch, autoimmunity, bullous pemphigoid, psoriasis, eosinophils, basophils

\section{INTRODUCTION}

IL-31 was first described by Dillon et al as a T cell-derived cytokine that was predominantly produced by The cells (1). Interestingly, mice which overexpressed IL-31 were observed to develop severe pruritus, alopecia and skin lesions (1). Furthermore, animal models of airway hypersensitivity exhibited increased IL-31 receptor expressions and these expressions, as well as those of IL-31 receptors in the skin, were also verified in respective human tissues (1). Human and mouse IL-31 share $31 \%$ amino acid homology and the genes for this cytokine are, respectively, located on chromosome 12q24.31 and chromosome 5 (1).

IL-31 is a member of the gp130/IL-6 family of cytokines and is a four helix bundle cytokine that acts as a ligand for the heterodimeric IL-31 receptor A (IL-31RA), a novel type I cytokine receptor, and the oncostatin $M$ receptor (OSMR), the latter of which increases IL-31 binding affinity to IL-31RA. Both of these IL-31 receptors are expressed on a variety of different cell types including $\mathrm{T}$ cells, dorsal root ganglia (DRG), keratinocytes, dendritic cells, eosinophils, basophils, and macrophages (2-7). The functional activity of IL-31 
appears to depend on the expression of both the IL-31RA and OSMR since, in basophils, we recently demonstrated that blocking of either receptor type decreases IL-31-induced IL-4 and IL-13 release (7).

Subsequent signaling following receptor complex binding involves the Janus kinase-signal transducer and activator of transcription pathway, the phosphoinositide-3-kinase-Akt pathway as well as the mitogen-activated protein kinase pathway (4, 8-10). IL-31 signaling controls a wide range of biological functions and immunomodulatory effects, such as the release of chemokines, proinflammatory cytokines, regulation of cell proliferation and stimulation of DRG sensory neurons which are responsible for induction of itch [reviewed in $(11,12)$ ].

\section{GENERAL PROPERTIES OF IL-31 IN SKIN DISEASES}

In dermatological diseases, IL-31 is of particular interest in terms of itch and inflammation as well as impaired skin-barrier function arising from IL-31-induced tissue remodeling $(13,14)$. The cytokine was not only found to induce severe pruritus in mice, where levels of IL-31 correlated with scratching behavior, but a NC/Nga mouse model of atopic dermatitis demonstrated the potential therapeutic benefit of blocking anti-IL-31 antibodies $(1,15,16)$. Before the discovery of IL-31, histamine was widely considered to be the most important pruritic mediator and the relative lack of therapeutic control of itch by H1antihistamines was ascribed following the discovery of additional H4-receptor input in pruritus [reviewed in (17)]. This is partly supported by a recent successful clinical trial using an H4receptor antagonist in atopic dermatitis (18), indicating potential future combinational $\mathrm{H} 1$ - and $\mathrm{H} 4$-receptor antagonist/inverse agonist approaches. However, recent data from human clinical trials using nemolizumab (CIM331), a humanized antibody against interleukin-31 receptor A, clearly indicates that IL-31 is an important mediator of itch in humans too $(19,20)$.

Alongside its pruritogenic actions, IL-31 has a proinflammatory role too due to the upregulation of proinflammatory gene expressions in $\mathrm{T}$ cells, including CCL2 and granulocyte colony-stimulating factor (21). Interestingly, CCL2 has recently been implicated in driving basophil trafficking in systemic lupus erythematosus (SLE) and in severe allergic reactions $(22,23)$. IL-31 release by $\mathrm{CD} 4+\mathrm{T}$ cells is mostly restricted to Th2 cells, although Th1 cells can produce this cytokine in vitro following exposure to IL-4 (21). Epidermal keratinocytes are also a major target for IL-31, where it induces chemokine gene expressions for GRO1 $\alpha$ (CXCL1), I-309 (CCL1), MIP-1 $\beta$ (CCL4), TARC (CCL17), MIP-3 $\beta$ (CCL19), MDC (CCL22), and MIP-3 (CCL23), [(1), reviewed in(11)]. Furthermore, Singh et al. showed that IL-31 increased epidermal basal-cell proliferation in mice resulting in thickening of the epidermal skin layer but increased transepidermal water loss (14). This impairment of skin barrier function occurs due to IL-31 decreasing filaggrin expression in human keratinocytes (24). Interestingly, reduced filaggrin expressions are strongly associated with atopic dermatitis and have been shown to enhance Staphylococcus aureus colonization $(24,25)$.

Increased levels of IL-31 have now been shown in various inflammatory skin diseases including prurigo nodularis (12), atopic dermatitis (26-28), contact eczema (29), chronic spontaneous urticaria (CsU) (30), as well as in a subset of patients with mastocytosis (31). In an animal model of atopic dermatitis anti-IL-31 treatment significantly reduced scratching in mice (16), underlining the important role of IL-31 in mediating pruritus. This seems to apply to humans too, where IL-31 levels were shown to correlate with disease severity in atopic dermatitis $(27,28)$. Interestingly, $\mathrm{CsU}$ patients respond to omalizumab therapy which was recently shown to be associated with reduced IL-31 serum levels (32). This suggests that this IL-31 may be modulated by IgE-dependent mechanisms and this further highlights the potential of anti-IL-31 as a therapeutic approaches as well as targeting IgE-positive effector cells.

\section{IL-31 IN AUTOIMMUNE SKIN DISEASES}

IL-31 has thus far been shown to play a prominent role in common inflammatory skin diseases, such as atopic dermatitis, particularly in relation to pruritus. However, since pruritus is also a major feature in bullous pemphigoid, chronic spontaneous urticaria $(\mathrm{CsU})$ and other autoimmune diseases there is a potential role for IL-31 in some of these diseases too.

\section{Chronic Spontaneous Urticaria}

It has long been recognized that autoimmune mechanisms are an important component of $\mathrm{CsU}$ [reviewed in (33)]. CsU is defined by the rapid appearance of pruritic wheals lasting $<24 \mathrm{~h}$ but which may occur repeatedly over a period of at least 6 weeks. The autoimmune association in $\mathrm{CsU}$ is either due to IgE mediated autoallergy against thyroid peroxidase or IgG auto-antibodies against the $\alpha$-subunit of the high-affinity IgE receptor(FceRI) and, more rarely, against IgE. All of these possible autoimmune mechanisms activate mast cells and basophils, cells which have been centrally implicated with CsU (34-36).

While mast cells and basophils are the main sources of histamine, antihistamine treatment in patients with $\mathrm{CsU}$ does not fully eliminate itch, suggesting that IL-31 may have some input in pruritic mechanisms associated with $\mathrm{CsU}$. Indeed, we observed increased IL-31 serum levels in CsU patients, although these levels were generally lower than those seen in atopic dermatitis patients (30). These observations have recently been confirmed by Lin et al. who demonstrated significantly higher levels of IL31 in $\mathrm{CsU}$ patients with most severe pruritus intensity compared to milder forms but not with urticarial activity per se (37). This supports the notion that IL-31 contributes to itch rather than other aspects of disease activity.

In our own investigations, we subsequently discovered that the main cellular sources of IL-31 in skin lesions of CsU patients are basophils (7). Basophils produced and released IL-31 in response to IgE-dependent stimulation and were even more responsive in terms of secreting the cytokine following incubation with the bacterial peptide $N$-Formylmethionyl-leucyl-phenylalanine (7). Basophils also expressed both IL-31 and OSMR receptors, and 


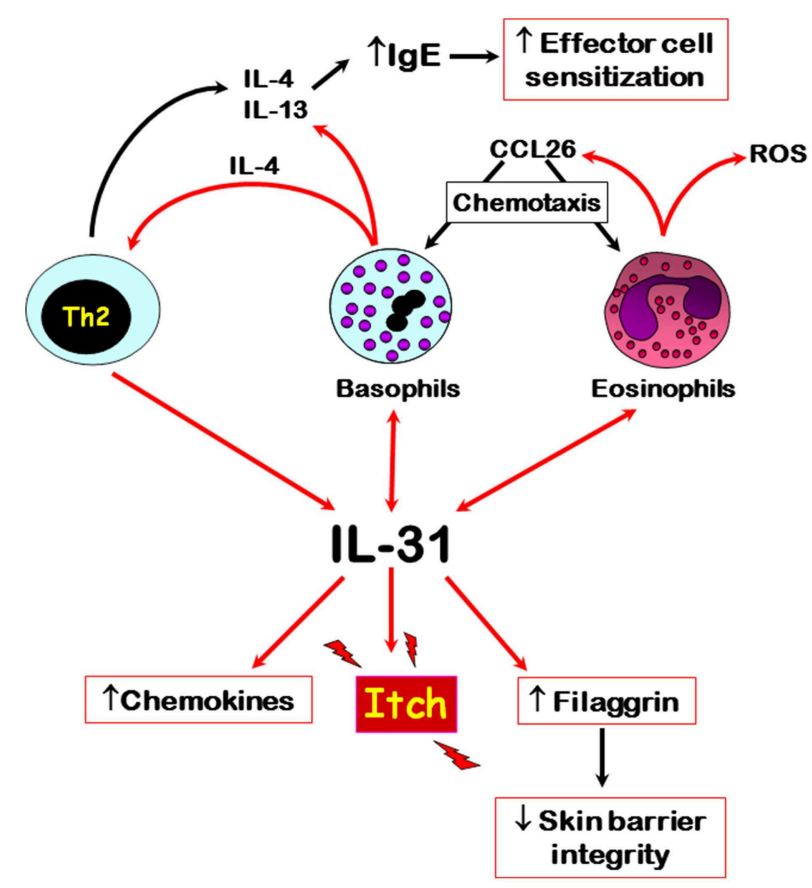

FIGURE 1 | Overview of the main cellular sources and potential roles of IL-31 in autoimmune skin diseases. Red arrows denote direct effects, black indirect effects. Double arrows denote autocrine activation.

were responsive to IL-31 stimulation which gave rise to release of the archetypal Th2-type cytokines IL-4 and IL-13 from these cells. Surprisingly, however, IL-31 failed to cause degranulation of basophils, as determined by the expression of the degranulation markers CD63 and CD203c as well as histamine release (7).

Since basophils are predominant sources of both IL31 and histamine, inhibition of basophil function is of therapeutic interest in controlling itch-related symptoms in CsU. Furthermore, basophils not only significantly infiltrate the skin in $\mathrm{CsU}$ (38) but are also crucial contributors of IL-4 and IL-13 which support IgE class-switching and, in the case of IL-4, also Th2 immunity [reviewed in (39)]. IgE-dependent basophil activation can be therapeutically targeted with the monoclonal antibody omalizumab, which prevents free-circulating IgE from binding to cells such as basophils and also mast cells, leading to the downregulation of cell-surface FcERI expressions as well as the degree of IgE sensitization. Since the autoimmune component of CsU is thought to involve autoantibodies against either FceRI or IgE a reduction of cell-surface IgE and/or FceRI due to omalizumab presents an important therapeutic strategy. Indeed, omalizumab has been used successfully to treat patients with CsU $(40,41)$. The fact that IL-31 levels are also reduced following omalizumab treatment further supports the role of basophils in $\mathrm{CsU}$ (32). This is underlined by reports of a rapid reduction in vivo of both FceRI and IgE expressions on basophils due to omalizumab (42). While mast cells may also be targeted by omalizumab, the reductions in FceRI receptor density resulting from omalizumab therapy are known to occur sooner in basophils than for skin mast cells, possibly due to a greater turnover of basophils compared to their skin tissue-fixed mast cell counterparts (43).

In addition to our observations regarding IL-31 inducing Th2type cytokine release from basophils, we found that the cytokine also facilitates basophil chemotaxis (7). This indicates that IL-31 plays a role in the orchestration and accumulation of basophils in inflammatory skin diseases such as CsU. Since basophils are majorly involved in the pathogenesis of $\mathrm{CsU}$, targeting IL31 directly (e.g., by nemolizumab) may prevent both IL-31mediated basophil recruitment as well as the autocrine effects of this cytokine in stimulating the release of IL-4 and IL-13 from basophils. Such approaches using nemolizumab (CIM331) have recently been tested successfully (also in terms of reducing itch) in atopic dermatitis in both humans and other primates (19, 20, 44-46). Similarly, the anti-canine-IL-31 monoclonal antibody, lokivetmab, has been used to treat atopic dermatitis in dogs (47-49). However, the potential clinical benefits of anti-IL31 monoclonal antibodies have yet to be reported for CsU (and indeed other autoimmune skin diseases).

\section{Bullous Pemphigoid}

The autoimmune blistering skin disease, bullous pemphigoid (BP), is accompanied by severe pruritus, thus suggesting possible involvement of IL-31. Indeed, Salz et al reported high IL-31 levels in BP blister fluids as well as an association of this cytokine with granulocytes (50). More recently, we also showed that IL31 is expressed in the lesional skin of BP patients, particularly in eosinophils from skin tissue and also within blister fluids (51). Moreover, eosinophils were demonstrated to be the major cellular source of IL-31 in BP and isolated peripheral blood eosinophils secreted substantial amounts of IL-31 (51). Similarly to basophils, IL-31 also has chemotactic effects on eosinophils and additionally stimulates these cells to release reactive oxygen species and the chemokine CCL26 (5).

It is, however, as yet unclear whether BP patients display elevated serum levels of IL-31, since the currently published literature has reported conflicting observations. Our own investigation showed only minor elevations in serum IL-31 levels vs. non-BP controls (51) compared to Salz et al (50), who observed significant increases, and Kulczycka-Siennicka et al. (52), who reported reduced levels of the cytokine. Despite these different observations regarding IL-31 serum levels, it is clear that eosinophils are one of the major sources for the increased IL-31 levels in BP blister fluids, which often contain a highly enriched accumulation of eosinophils. Because BP patients experience pruritus particularly in lesional skin the increases in IL-31 levels in blister fluids offer a plausible explanation for this localized itch.

Basophils have also been reported to be associated with BP (53) but their potential contribution to IL-31 in this disease is not yet known. Eosinophil-derived IL-31 may possibly participate in the trafficking of basophils to lesional tissues affected by BP and this may further be supported by IL-31-induced CCL26 release from eosinophils (5). Furthermore, there are several case reports of successful therapy of BP using omalizumab, suggesting potential basophil involvement (54-56). However, Freire et al recently showed that the mast cells and eosinophils make up most of the IgE-expressing cells in BP skin (57) and both cell 
types are widely reported to participate in various autoimmune skin diseases [reviewed in $(58,59)$ ]. It is thus conceivable that the clinical benefit of omalizumab therapy may largely due to a reduction in eosinophil and mast cell function.

\section{Psoriasis}

It was originally thought that IL-31 does not play a role in psoriasis, based on comparisons of cellular expressions of the cytokine (both at mRNA level and immunoreactivity) together with controls $(12,29,60)$. However, more recent investigations have reported that serum IL-31 levels are significantly elevated in psoriasis and that chronic itch associated with psoriatic skin is accompanied by increased transcription of IL-31 (61, 62). Narbutt et al further showed that IL-31 serum levels were significantly reduced after narrowband UVB phototherapy, coinciding with a substantial reduction in pruritus in these patients (61). This study indicates that itch accompanying psoriasis might be associated with IL-31. Interestingly, skin mast cells have been shown to express elevated IL-31 in psoriatic skin compared to healthy controls (63). In contrast, however, Czarnecka-Operacz et al. failed to observe any correlation between itch severity in psoriasis and IL-31 (64). On balance, and despite the possibility that it may contribute to pruritic forms of the disease, the currently published literature does not yet provide a clear consensus regarding the role of IL-31 in psoriasis per se.

\section{Autoimmune Connective Tissue Diseases Affecting the Skin}

Pruritus is a prominent symptom in several autoimmune connective tissue diseases such as lupus and dermatomyositis, although these diseases can affect multiple organ systems and are often supervised by dermatologists. In lupus erythematosus there is currently only sparse evidence to suggest a role of IL31 and, as yet, no reports specifically dealing with cutaneous forms of this autoimmune disease. Although pruritus does often accompany cutaneous lupus erythematosus it is usually mild in severity and (65), possibly indicating that IL-31 is not a major player in this disease. In systemic lupus erythematosus (SLE) IL-31 serum levels were not shown to be significantly increased compared to healthy controls (66). However, in stark contrast, a more recent study reported significant increases in IL-31 serum levels in SLE as well as identification of IL-31 polymorphisms that were associated with SLE in the Chinese population (67). While the role of IL-31 in SLE is still unclear these IL-31 polymorphisms may nonetheless serve as novel genetic markers of susceptibility to SLE (67).

Dermatomyositis is another autoimmune disease that involves the skin and is sometimes involves considerable pruritus(68), although the muscles and sometimes the lungs can also be affected. In a recent article, Kim et al showed that itch correlated

\section{REFERENCES}

1. Dillon SR, Sprecher C, Hammond A, Bilsborough J, RosenfeldFranklin M, Presnell SR, et al. Interleukin 31, a cytokine produced with increased cutaneous severity where IL-31 and IL-31RA gene expressions in lesional skin were upregulated compared with either non-lesional skin or that from healthy controls (69). IL-31 mRNA expression also positively correlated with itch score and immunoreactivity for IL-31 and IL-31RA was greater in lesional skin. Furthermore, lesional dermatomyositis skin contained significantly more IL-31-producing cells, of which CD4+ cells were the most abundant IL-31-expressing cell type (70).

\section{Alopecia Areata}

In addition to its role in pruritic skin diseases, IL-31 was originally also associated with alopecia areata, an autoimmune disease involving inflammation of the hair follicles and a loss of immune privilege [reviewed in (70)]. However, although IL-31 and hair loss was described in mice (1) it was not subsequently observed in patients with alopecia areata (60).

\section{CONCLUDING REMARKS}

The published literature to date shows that IL-31 is differentially associated with autoimmune skin diseases, especially those where pruritus is a major symptom, such as CsU and bullous pemphigoid. Here, recent evidence shows that basophils and eosinophils are major sources of this cytokine, respectively, especially within affected skin tissues. However, the input of other IL-31-producing cells, especially CD4+ T cells, in these autoimmune diseases still needs to be elucidated in terms of IL31-mediated immunomodulatory roles. IL-31 possibly plays a role in the trafficking of basophils to affected tissue sites because of its known actions in supporting the release CCL2 and CCL26 chemokines. Basophil-derived IL-4, the release of which is also driven by IL-31, may support the development of Th2 cells and subsequent further IL-31 production. The interplay of IL31 and various immune cells that are known to play a role in autoimmune skin diseases is summarized in Figure 1. Overall, IL-31 is a crucial driver for pruritus in certain autoimmune skin diseases and the recent development of blocking antibodies offers exciting new therapeutic opportunities to combat itchrelated symptoms.

\section{AUTHOR CONTRIBUTIONS}

All authors listed have made a substantial, direct and intellectual contribution to the work, and approved it for publication.

\section{ACKNOWLEDGMENTS}

The authors would like to thank the Deutsche Forschungsgemeinschaft for providing research funding (Translationale Pruritusforschung RA 1026/3-1).

by activated $\mathrm{T}$ cells, induces dermatitis in mice. Nat Immunol. (2004) 5:752-60. doi: 10.1038/ni1084

2. Bando T, Morikawa Y, Komori T, Senba E. Complete overlap of interleukin31 receptor $\mathrm{A}$ and oncostatin $\mathrm{M}$ receptor beta in the adult dorsal root 
ganglia with distinct developmental expression patterns. Neuroscience. (2006) 142:1263-71. doi: 10.1016/j.neuroscience.2006.07.009

3. Horejs-Hoeck J, Schwarz H, Lamprecht S, Maier E, Hainzl S, Schmittner M, et al. Dendritic cells activated by IFN-gamma/STAT1 express IL-31 receptor and release proinflammatory mediators upon IL-31 treatment. J Immunol. (2012) 188:5319-26. doi: 10.4049/jimmunol.1101044

4. Kasraie S, Niebuhr M, Baumert K, Werfel T. Functional effects of interleukin 31 in human primary keratinocytes. Allergy. (2011) 66:84552. doi: 10.1111/j.1398-9995.2011.02545.x

5. Kunsleben N, Rüdrich U, Gehring M, Novak N, Kapp A, Raap U. IL-31 induces chemotaxis, calcium mobilization, release of reactive oxygen species, and CCL26 in eosinophils, which are capable to release IL-31. J Invest Dermatol. (2015) 135:1908-11. doi: 10.1038/jid.2015.106

6. Kasraie S, Niebuhr M, Werfel T. Interleukin (IL)-31 induces proinflammatory cytokines in human monocytes and macrophages following stimulation with staphylococcal exotoxins. Allergy. (2010) 65:712-21. doi: 10.1111/j.1398-9995.2009.02255.x

7. Raap U, Gehring M, Kleiner S, Rüdrich U, Eiz-Vesper B, Haas H, et al. Human basophils are a source of - and are differentially activated by - IL-31. Clin Exp Allergy. (2017) 47:499-508. doi: 10.1111/cea.12875

8. Diveu C, Venereau E, Froger J, Ravon E, Grimaud L, Rousseau F, et al. Molecular and functional characterization of a soluble form of oncostatin M/interleukin-31 shared receptor. J Biol Chem. (2006) 281:3667382. doi: 10.1074/jbc.M607005200

9. Chattopadhyay S, Tracy E, Liang P, Robledo O, Rose-John S, Baumann H. Interleukin-31 and oncostatin-M mediate distinct signaling reactions and response patterns in lung epithelial cells. J Biol Chem. (2007) 282:301426. doi: 10.1074/jbc.M609655200

10. Dambacher J, Beigel F, Seiderer J, Haller D, Göke B, Auernhammer CJ, et al. Interleukin 31 mediates MAP kinase and STAT1/3 activation in intestinal epithelial cells and its expression is upregulated in inflammatory bowel disease. Gut. (2007) 56:1257-65. doi: 10.1136/gut.2006.118679

11. Zhang Q, Putheti P, Zhou Q, Liu Q, Gao W. Structures and biological functions of IL-31 and IL-31 receptors. Cytokine Growth Factor Rev. (2008) 19:347-56. doi: 10.1016/j.cytogfr.2008.08.003

12. Sonkoly E, Muller A, Lauerma AI, Pivarcsi A, Soto H, Kemeny L, et al. IL-31: a new link between T cells and pruritus in atopic skin inflammation. J Allergy Clin Immunol. (2006) 117: 411-7. doi: 10.1016/j.jaci.2005.10.033

13. Ständer S, Weisshaar E, Raap U. Emerging drugs for the treatment of pruritus. Expert Opin Emerg Drugs. (2015) 20:51521. doi: $10.1517 / 14728214.2015 .1051964$

14. Singh B, Jegga AG, Shanmukhappa KS, Edukulla R, Khurana Hershey GH, Medvedovic M, et al. IL-31-driven skin remodeling involves epidermal cell proliferation and thickening that lead to impaired skin-barrier function. PLoS ONE. (2016) 11:e0161877. doi: 10.1371/journal.pone.0161877

15. Takaoka A, Arai I, Sugimoto M, Yamaguchi A, Tanaka M, Nakaike S. Expression of IL-31 gene transcripts in NC/Nga mice with atopic dermatitis. Eur J Pharmacol. (2005) 516:180-1. doi: 10.1016/j.ejphar.2005. 04.040

16. Grimstad O, Sawanobori Y, Vestergaard C, Bilsborough J, Olsen UB, Gronhoj-Larsen C, et al. Anti-interleukin-31-antibodies ameliorate scratching behaviour in NC/Nga mice: a model of atopic dermatitis. Exp Dermatol. (2009) 18:35-43. doi: 10.1111/j.1600-0625.2008.00766.x

17. Gutzmer R, Gschwandtner M, Rossbach K, Mommert S, Werfel T, Kietzmann $\mathrm{M}$, et al. Pathogenetic and therapeutic implications of the histamine H4 receptor in inflammatory skin diseases and pruritus. Front Biosci. (2011) 3:985-94. doi: $10.2741 / \mathrm{s} 203$

18. Werfel T, Layton G, Yeadon M, Whitlock L, Osterloh I, Jimenez P, et al. Efficacy and safety of the histamine H4 receptor antagonist ZPL-3893787 in patients with atopic dermatitis. J Allergy Clin Immunol. (2018) 143:1830-7.e4. doi: 10.1016/j.jaci.2018.07.047

19. Nemoto O, Furue M, Nakagawa H, Shiramoto M, Hanada R, Matsuki S et al. The first trial of CIM331, a humanized antihuman interleukin-31 receptor A antibody, in healthy volunteers and patients with atopic dermatitis to evaluate safety, tolerability and pharmacokinetics of a single dose in a randomized, double-blind, placebo-controlled study. Br J Dermatol. (2016) 174:296-304. doi: 10.1111/bjd.14207
20. Ruzicka T, Hanifin JM, Furue M, Pulka G, Mlynarczyk I, Wollenberg A, et al. Anti-interleukin-31 receptor A antibody for atopic dermatitis. $N$ Engl J Med. (2017) 376:826-35. doi: 10.1056/NEJMoa1606490

21. Stott B, Lavender P, Lehmann S, Pennino D, Durham S, Schmidt-Weber CB. Human IL-31 is induced by IL-4 and promotes TH2-driven inflammation. $J$ Allergy Clin Immunol. (2013) 132:446-54. doi: 10.1016/j.jaci.2013.03.050

22. Pan Q, Feng Y, Peng Y, Zhou H, Deng Z, Li L, et al. Basophil recruitment to skin lesions of patients with systemic lupus erythematosus mediated by CCR1 and CCR2. Cell Physiol Biochem. (2017) 43:832-39. doi: 10.1159/000481609

23. Korosec P, Turner PJ, Silar M, Kopac P, Kosnik M, Gibbs BF, et al. Basophils, high-affinity IgE receptors, and CCL2 in human anaphylaxis. J Allergy Clin Immunol. (2017) 140:750-58. doi: 10.1016/j.jaci.2016.12.989

24. Cornelissen C, Marquardt Y, Czaja K, Wenzel J, Frank J, LüscherFirzlaff J, et al. IL-31 regulates differentiation and filaggrin expression in human organotypic skin models. J Allergy Clin Immunol. (2012) 129:42633. doi: 10.1016/j.jaci.2011.10.042

25. van Drongelen V, Haisma EM, Out-Luiting JJ, Nibbering PH, El Ghalbzouri A. Reduced filaggrin expression is accompanied by increased Staphylococcus aureus colonization of epidermal skin models. Clin Exp Allergy. (2014) 44:1515-24. doi: 10.1111/cea.12443

26. Bilsborough J, Leung DY, Maurer M, Howell M, Boguniewicz M, Yao L, et al. IL-31 is associated with cutaneous lymphocyte antigen-positive skin homing $\mathrm{T}$ cells in patients with atopic dermatitis. J Allergy Clin Immunol. (2006) 117:418-25. doi: 10.1016/j.jaci.2005.10.046

27. Raap U, Wichmann K, Bruder M, Stander S, Wedi B, Kapp A, et al. Correlation of IL-31 serum levels with severity of atopic dermatitis. J Allergy Clin Immunol. (2008) 122:421-23. doi: 10.1016/j.jaci.2008.05.047

28. Raap U, Weissmantel S, Gehring M, Eisenberg AM, Kapp A, Folster-Holst R. IL-31 significantly correlates with disease activity and Th2 cytokine levels in children with atopic dermatitis. Pediatr Allergy Immunol. (2012) 23:28588. doi: 10.1111/j.1399-3038.2011.01241.x

29. Neis MM, Peters B, Dreuw A, Wenzel J, Bieber T, Mauch C, et al. Enhanced expression levels of IL-31 correlate with IL-4 and IL-13 in atopic and allergic contact dermatitis. J Allergy Clin Immunol. (2006) 118:93037. doi: 10.1016/j.jaci.2006.07.015

30. Raap U, Wieczorek D, Gehring M, Pauls I, Stander S, Kapp A, et al. Increased levels of serum IL-31 in chronic spontaneous urticaria. Exp Dermatol. (2010) 19:464-66. doi: 10.1111/j.1600-0625.2010.01067.x

31. Hartmann K, Wagner N, Rabenhorst A, Pflanz L, Leja S, Forster A, et al. Serum IL-31 levels are increased in a subset of patients with mastocytosis and correlate with disease severity in adult patients. J Allergy Clin Immunol. (2013) 132:232-35. doi: 10.1016/j.jaci.2012.11.008

32. Altrichter S, Hawro T, Hanel K, Czaja K, Luscher B, Maurer M, et al. Successful omalizumab treatment in chronic spontaneous urticaria is associated with lowering of serum IL-31 levels. J Eur Acad Dermatol Venereol. (2016) 30:45455. doi: $10.1111 / \mathrm{jdv} .12831$

33. Philpott H, Kette F, Hissaria P, Gillis D, Smith W. Chronic urticaria: the autoimmune paradigm. Intern Med J. (2008) 38:852-7. doi: 10.1111/j.1445-5994.2008.01673.x

34. Altrichter S, Peter HJ, Pisarevskaja D, Metz M, Martus P, Maurer M. IgE mediated autoallergy against thyroid peroxidase - a novel pathomechanism of chronic spontaneous urticaria? PLoS ONE. (2011) 6:e14794. doi: 10.1371/journal.pone.0014794

35. Rauber MM, Pickert J, Holiangu L, Möbs C, Pfützner W. Functional and phenotypic analysis of basophils allows determining distinct subtypes in patients with chronic urticaria. Allergy. (2017) 72:1904-11. doi: 10.1111/all.13215

36. Church MK, Kolkhir P, Metz M, Maurer M. The role and relevance of mast cells in urticaria. Immunol Rev. (2018) 282:232-47. doi: 10.1111/imr.12632

37. Lin W, Zhou Q, Liu C, Ying M, Xu S. Increased plasma IL-17, IL31, and IL-33 levels in chronic spontaneous urticaria. Sci Rep. (2017) 7:17797. doi: 10.1038/s41598-017-18187-Z

38. Ying S, Kikuchi Y, Meng Q, Kay AB, Kaplan AP. TH1/TH2 cytokines and inflammatory cells in skin biopsy specimens from patients with chronic idiopathic urticaria: comparison with the allergen-induced latephase cutaneous reaction. J Allergy Clin Immunol. (2002) 109:694700. doi: 10.1067/mai.2002.123236 
39. Varricchi G, Raap U, Rivellese F, Marone G, Gibbs BF. Human mast cells and basophils-How are they similar how are they different? Immunol Rev. (2018) 282:8-34. doi: 10.1111/imr.12627

40. Magerl M, Staubach P, Altrichter S, Ardelean E, Krause K, Metz $\mathrm{M}$, et al. Effective treatment of therapy-resistant chronic spontaneous urticaria with omalizumab. J Allergy Clin Immunol. (2010) 126:6656. doi: 10.1016/j.jaci.2010.05.047

41. Maurer M, Altrichter S, Bieber T, Biedermann T, Bräutigam M, Seyfried S, et al. Efficacy and safety of omalizumab in patients with chronic urticaria who exhibit IgE against thyroperoxidase. J Allergy Clin Immunol. (2011) 128:202-9. doi: 10.1016/j.jaci.2011.04.038

42. Metz M, Staubach P, Bauer A, Brehler R, Gericke J, Kangas M, et al. Clinical efficacy of omalizumab in chronic spontaneous urticaria is associated with a reduction of FceRI-positive cells in the skin. Theranostics. (2017) 7:126676. doi: 10.7150/thno.18304

43. Beck LA, Marcotte GV, MacGlashan D, Togias A, Saini S. Omalizumabinduced reductions in mast cell Fce psilon RI expression and function. $J$ Allergy Clin Immunol. (2004) 114:527-30. doi: 10.1016/j.jaci.2004.06.032

44. Fioranelli M, Roccia MG, Lotti T. Therapy with anti-interleukin31 receptor A antibody for atopic dermatitis. Dermatol Ther. (2017) 30:e12490. doi: 10.1111/dth.12490

45. Kabashima K, Furue M, Hanifin JM, Pulka G, Wollenberg A, Galus R, et al. Nemolizumab in patients with moderate-to-severe atopic dermatitis: Randomized, phase II, long-term extension study. J Allergy Clin Immunol. (2018) 142:1121-30. doi: 10.1016/j.jaci.2018.03.018

46. Oyama S, Kitamura H, Kuramochi T, Higuchi Y, Matsushita H, Suzuki T, et al. Cynomolgus monkey model of interleukin-31-induced scratching depicts blockade of human interleukin-31 receptor A by a humanized monoclonal antibody. Exp Dermatol. (2018) 27:14-21. doi: 10.1111/exd.13236

47. Tamamoto-Mochizuki C, Paps JS, Olivry T. Proactive maintenance therapy of canine atopic dermatitis with the anti-IL-31 lokivetmab. can a monoclonal antibody blocking a single cytokine prevent allergy flares? Vet Dermatol. (2019) 30:98-104. doi: 10.1111/vde.12715

48. Michels GM, Walsh KF, Kryda KA, Mahabir SP, Walters RR, Hoevers JD, et al. A blinded, randomized, placebo-controlled trial of the safety of lokivetmab (ZTS-00103289), a caninized anti-canine IL-31 monoclonal antibody in client-owned dogs with atopic dermatitis. Vet Dermatol. (2016) 27:505-e136. doi: 10.1111/vde.12364

49. Moyaert H, Van Brussel L, Borowski S, Escalada M, Mahabir SP, Walters $\mathrm{RR}$, et al. A blinded, randomized clinical trial evaluating the efficacy and safety of lokivetmab compared to ciclosporin in client-owned dogs with atopic dermatitis. Vet Dermatol. (2017) 28:593-e145. doi: 10.1111/vde.12478

50. Salz M, Haeberle S, Hoffmann J, Enk AH, Hadaschik EN. Elevated IL31 serum levels in bullous pemphigoid patients correlate with eosinophil numbers and are associated with BP180-IgE. J Dermatol Sci. (2017) 87:30911. doi: 10.1016/j.jdermsci.2017.07.019

51. Rüdrich U, Gehring M, Papakonstantinou E, Illerhaus A, Engmann J, Kapp A, et al. Eosinophils are a major source of interleukin-31 in bullous pemphigoid. Acta Derm Venereol. (2018) 98:766-71. doi: 10.2340/00015555-2951

52. Kulczycka-Siennicka L, Cynkier A, Waszczykowska E, Wozniacka A, Zebrowska A. The role of Intereukin-31 in pathogenesis of itch and its intensity in a course of bullous pemphigoid and dermatitis herpetiformis. Biomed Res Int. (2017) 2017:5965492. doi: 10.1155/2017/5965492

53. Ito Y, Satoh T, Takayama K, Miyagishi C, Walls AF, Yokozeki H. Basophil recruitment and activation in inflammatory skin diseases. Allergy. (2011) 66:1107-13. doi: 10.1111/j.1398-9995.2011.02570.x

54. Dufour C, Souillet AL, Chaneliere C, Jouen F, Bodemer C, Jullien D, et al. Successful management of severe infant bullous pemphigoid with omalizumab. Br J Dermatol. (2012) 166:11402. doi: 10.1111/j.1365-2133.2011.10748.x

55. London VA, Kim GH, Fairley JA, Woodley DT. Successful treatment of bullous pemphigoid with omalizumab. Arch Dermatol. (2012) 148:12413. doi: 10.1001/archdermatol.2012.1604
56. Menzinger S, Kaya G, Schmidt E, Fontao L, Laffitte E. Biological and clinical response to omalizumab in a patient with bullous pemphigoid. Acta Derm Venereol. (2018) 98:284-6. doi: 10.2340/00015555-2845

57. Freire PC, Muñoz CH1, Stingl G. IgE autoreactivity in bullous pemphigoid: eosinophils and mast cells as major targets of pathogenic immune reactants. Br J Dermatol. (2017) 177:1644-53. doi: 10.1111/bjd.15924

58. Diny NL, Rose NR, Ciháková D. Eosinophils in autoimmune diseases. Front Immunol. (2017) 8:484. doi: 10.3389/fimmu.2017.00484

59. Fang H, Zhang Y, Li N, Wang G, Liu Z. The autoimmune skin disease bullous pemphigoid: the role of mast cells in autoantibody-induced tissue injury. Front Immunol. (2018) 9:407. doi: 10.3389/fimmu.2018.00407

60. Nobbe S, Dziunycz P, Mühleisen B, Bilsborough J, Dillon SR, French LE, et al. IL-31 expression by inflammatory cells is preferentially elevated in atopic dermatitis. Acta Derm Venereol. (2012) 92:24-8. doi: 10.2340/00015555 $-1191$

61. Narbutt J, Olejniczak I, Sobolewska-Sztychny D, Sysa-Jedrzejowska A, SłowikKwiatkowska I, Hawro T, et al. Narrow band ultraviolet B irradiations cause alteration in interleukin-31 serum level in psoriatic patients. Arch Dermatol Res. (2013) 305:191-5. doi: 10.1007/s00403-012-1293-6

62. Nattkemper LA, Tey HL, Valdes-Rodriguez R, Lee H, Mollanazar NK, Albornoz C, et al. The genetics of chronic itch: gene expression in the skin of patients with atopic dermatitis and psoriasis with severe itch. J Invest Dermatol. (2018) 138:1311-7. doi: 10.1016/j.jid.2017.12.029

63. Niyonsaba F, Ushio H, Hara M, Yokoi H, Tominaga M, Takamori K, et al. Antimicrobial peptides human beta-defensins and cathelicidin LL-37 induce the secretion of a pruritogenic cytokine IL-31 by human mast cells. J Immunol. (2010) 184:3526-34. doi: 10.4049/jimmunol.0900712

64. Czarnecka-Operacz M, Polanska A, Klimanska M, Teresiak-Mikołajczak E, Molinska-Glura M, Adamski Z, et al. Itching sensation in psoriatic patients and its relation to body mass index and IL-17 and IL-31 concentrations. Postepy Dermatol Alergol. (2015) 32:426-30. doi: 10.5114/pdia.2015. 56097

65. Samotij D, Szczech J, Kushner CJ, Mowla MR, Danczak-Pazdrowska A, Antiga E, et al. Prevalence of pruritus in cutaneous lupus erythematosus: brief report of a multicenter, multinational cross-sectional study. Biomed Res Int. (2018) 2018:3491798. doi: 10.1155/2018/3491798

66. Zhang M, Xu WD, Zhu Y, Wen PF, Leng RX, Pan HF, et al. Serum levels of cytokines in systemic lupus erythematosus: association study in a chinese population. Z Rheumatol. (2014) 73:277-80. doi: 10.1007/s00393-013-1274-y

67. Huang HT, Chen JM, Guo J, Lan Y, Wei YS. The association of interleukin-31 polymorphisms with interleukin-31 serum levels and risk of systemic lupus erythematosus. Rheumatol Int. (2016) 36:799-805. doi: 10.1007/s00296-016-3422-6

68. Shirani Z, Kucenic MJ, Carroll CL, Fleischer AB Jr, Feldman SR, Yosipovitch G, et al. Pruritus in adult dermatomyositis. Clin Exp Dermatol. (2004) 29:2736. doi: 10.1111/j.1365-2230.2004.01510.x

69. Kim HJ, Zeidi M, Bonciani D, Pena SM, Tiao J, Sahu S, et al. Itch in dermatomyositis: the role of increased skin interleukin-31. Br J Dermatol. (2018) 179:669-78. doi: 10.1111/bjd.16498

70. Rajabi F, Drake LA, Senna MM, Rezaei N. Alopecia areata: a review of disease pathogenesis. Br J Dermatol. (2018) 179:1033-48. doi: 10.1111/bjd.16808

Conflict of Interest Statement: The authors declare that the research was conducted in the absence of any commercial or financial relationships that could be construed as a potential conflict of interest.

Copyright (c) 2019 Gibbs, Patsinakidis and Raap. This is an open-access article distributed under the terms of the Creative Commons Attribution License (CC BY). The use, distribution or reproduction in other forums is permitted, provided the original author(s) and the copyright owner(s) are credited and that the original publication in this journal is cited, in accordance with accepted academic practice. No use, distribution or reproduction is permitted which does not comply with these terms. 